\title{
WIESŁAW ŚMIGIEL \\ Syndrom myślenia grupowego jako zagrożenie dla funkcjonowania grup kościelnych
}

W Kościele grupy o zróżnicowanej strukturze i zadaniach funkcjonowały od dawna, przykładem tego są bractwa, stowarzyszenia i zakony. Jednak prawdziwy rozwój grup kościelnych nastąpił po Soborze Watykańskim II, kiedy to powstały i zaczęły się rozwijać zróżnicowane formy zrzeszeń katolików, określane w teologii jako stowarzyszenia, grupy, wspólnoty i ruchy (por. ChL 29). Ten nowy dynamizm, dotyczący ilości, różnorodności i żywotności zrzeszeń, określony został jako „wiosna Kościoła”, a Adhortacja apostolska Christifideles laici nazwała czasy współczesne „nową epoką zrzeszeń katolików świeckich” (ChL 29).

Grupy kościelne, bez względu na to, jaki mają cel, zawsze funkcjonują w kontekście eklezjalnym i tylko w nim mogą się prawidłowo rozwijać. Są one wyrazem bogactwa charyzmatów, którymi Duch Święty przyozdabia Kościół w całkowicie wolny i trudny po przewidzenia sposób. Jednak w wymiarze horyzontalnym funkcjonują one według zasad, które są charakterystyczne dla wszystkich grup społecznych. Dlatego są one również narażone na błędy i dewiacje. Jeśli są grupami doradczymi, to moga popierać lub proponować złe rozwiązania, a jeśli są zrzeszeniami o charakterze formacyjnym, to wskutek nieprawidłowości mogą działać na szkodę swoich członków, całego Kościoła lub nawet zamienić się w sektę. Zatem, nie zapominając o ich specyfice, warto analizować poszczególne elementy dynamiki grupowej w odniesieniu do zrzeszeń kościelnych, aby polepszyć ich funkcjonowanie i ustrzec przed błędnymi decyzjami.

Trudno przecenić znaczenie grup religijnych dla odnowy Kościoła. Jednak nie wolno zapominać, że wiele grup oderwało się od wspólnoty Kościoła i wy-

${ }^{1}$ A. S c hu l z: Wiosna Kościoła w Polsce. W: Leksykon ruchów i stowarzyszeń w Kościele. Red. A. P e trow a - W a s i 1 e w i c z. Warszawa (KAI) 2000 s. 9. 
rządziło swoim członkom szkodę, zamieniając się w grupy destrukcyjne. Takie doświadczenia zobowiązują teoretyków i praktyków duszpasterstwa, aby pogłębiali swoją wiedzę z zakresu dynamiki grupowej i roztropnie aplikowali ją do zrzeszeń kościelnych.

Przez zastosowany w tym artykule termin ,grupy kościelne”, należy rozumieć wszelkie formy zrzeszeń katolików (ruchy, wspólnoty, stowarzyszenia, grupy nieformalne) oraz grupy doradcze, które w jakimś stopniu uczestniczą w procesie podejmowania decyzji. Kościół, kierując się wolą swojego założyciela Jezusa Chrystusa, posiada strukturę hierarchiczną i nie funkcjonuje według zasad demokratycznych. Jednak po Soborze Watykańskim II została podkreślona zasada kolegialności (łac. colligere - łączyć, gromadzić), która wynika z apostolskości Kościoła i jest sposobem sprawowania władzy. Związana jest ona z pasterską posługą biskupów $\mathrm{w}$ jedności $\mathrm{z}$ papieżem i pod jego przewodnictwem, ale przejawia się również $\mathrm{w}$ łączności biskupa diecezjalnego z jego prezbiterami, diakonami i katolikami świeckimi. Zatem pośrednio zasada kolegialności rozciąga się na działanie różnego rodzaju grup doradczych w Kościele. Konkretnymi przykładami takich grup są: rada kapłańska, rady kurialne, diecezjalna rada duszpasterska, rada parafialna (duszpasterska i ekonomiczna) oraz inne rady w zależności od specyfiki danej diecezji.

Syndrom myślenia grupowego to jedno $\mathrm{z}$ poważniejszych zagrożeń dla wszystkich grup, a szczególnie małych i spójnych. Najogólniej występuje on wówczas, gdy w grupie dążenie do jednomyślności wyzwala postawy konformistyczne, co z kolei zamyka grupę i sprawia, że traci ona kontakt z rzeczywistością i podejmuje szkodliwe decyzje. W społecznościach świeckich najczęściej myślenie grupowe dotyka zespoły ustalające strategie działan i podejmujące decyzje. Jednak specyfika funkcjonowania kościelnych grup doradczych sprawia, że znajdują się one $\mathrm{w}$ grupie wysokiego ryzyka wystapienia myślenia grupowego. Niemal modelowo przystają one do grup, w których stwierdzono takie zjawisko. Natomiast grupy formacyjne posiadają raczej luźniejszą strukturę organizacyjną i zazwyczaj są kontrolowane z zewnątrz przez hierarchię kościelną, stąd ryzyko wystapienia myślenia grupowego jest nieco mniejsze.

\section{Pojęcie syndromu myślenie grupowego}

Pojęcie syndromu myślenia grupowego wprowadził do psychologii społecznej amerykański badacz Irwing Janis ${ }^{2}$. Opierając się na wydarzeniach z historii Stanów Zjednoczonych Ameryki, opracował teorię dotyczącą podejmowania

\footnotetext{
${ }^{2}$ Zob. I. L. J a n i s: Victims of grupthink: Boston (Houghton Mifflin) 1972; T e n ż e: Grupphink. Boston (Houghton Mifflin) 1982.
} 
decyzji w grupie ${ }^{3}$. Zaobserwował zespół nieprawidłowości, który nazwał myśleniem grupowym.

Syndrom myślenia grupowego występuje wówczas, gdy dążenie do spójności i solidarności grupy jest ważniejsze, niż realistyczna ocena sytuacji i podejmowanie najlepszych z punktu widzenia interesu grupy decyzji ${ }^{4}$. Zatem wewnętrzna dynamika grupy przeważa nad motywacją do podjęcia decyzji merytorycznie zasadnych ${ }^{5}$. Zjawisko to pojawia się, kiedy grupa traci kontakt ze światem $^{6}$. Grupa nie jest świadoma tego zagrożenia i ma głębokie przekonanie, że dobrze wypełnia swoje zadania. Syndrom ten dotyczy wszystkich spójnych grup, które chcą podjąć jakąkolwiek decyzję. Opisany przez Janisa syndrom został potwierdzony w badaniach eksperymentalnych ${ }^{7}$.

Okoliczności sprzyjających pojawieniu się syndromu myślenia grupowego jest kilka. Główną przyczyną jest duża spoistość grupy, która występuje wówczas, gdy grupa zapewnia prestiż i jest atrakcyjna dla członków. Wśród innych przyczyn wymienia się dwa rodzaje. Pierwszy, to podstawowe wady struktury grupy: izolacja grupy, brak tradycji bezstronnego przywództwa, brak norm wymagających stosowania właściwych procedur decyzyjnych oraz homogeniczność pochodzenia społecznego i pozycji ideologicznej członków grupy. Drugi rodzaj przyczyn powstawania myślenia grupowego to bezpośredni kontekst, $\mathrm{w}$ jakim działa grupa: silny stres spowodowany przez zewnętrzne zagrożenia, niewielkie nadzieje na znalezienie lepszego niż proponowane przez przywódcę rozwiązanie,

\footnotetext{
${ }^{3} \mathrm{~J}$ a n is, a później również inni badacze przeanalizowali szereg wydarzeń historycznych i zaobserwowali podobne warunki, symptomy i skutki, które są charakterystyczne dla myślenia grupowego. Do błędnych decyzji spowodowanych myśleniem grupowym zaliczono między innymi: błąd popełniony przez dowództwo wojskowe USA w Pearl Harbor w związku z przewidywaniem ataku Japończyków w 1941 r.; decyzje o inwazji na Koreę Południowa w 1950 r.; decyzję o akcji w Zatoce Świń na Kubie, która zakończyła się całkowitą porażką; decyzję prezydenta Johnsona o eskalacji wojny w Wietnamie; zatuszowanie afery Watergate przez prezydenta N ix o n a i jego doradców; katastrofę wahadłowca "Challenger” w 1986 r., choć inżynierowie przestrzegali przed możliwością awarii.

${ }^{4}$ Por. E. A r o n s o n, T. D. W il s o n, R. M. A k e r t: Psychologia spoleczna. Serce i umyst. Poznań (Zysk i S-ka) 1997 s. 380.

${ }^{5}$ Por. B. W o j c is zk e: Człowiek wśród ludzi. Zarys psychologii społecznej. Warszawa (Wydawnictwo Naukowe Scholar) 2002 s. 402.

${ }^{6}$ Por. C. K. O y s t e r: Grupy. Poznań (Zysk i S-ka) 2002 s. 353.

${ }^{7}$ Zob. J. A. C o u rtrg h t: A laboratory investigation og grupthink. „Communication Monographs" R. 1978 nr 45 s. 229-246; M. R. C a 11 a w a y, J. K. E s t e r: Groupthink: Effects of cohesiveness and problem-solving procedures on grup decision making. „Social Behavior and Personality”. R. 1984 nr 12 s. 157-164; C. M c C a u le y: The nature od social influense in grupthonk: Comppliance and internalization. „Journal of Personality and Social Psychology”. R. $1989 \mathrm{nr} 57$ s. 250-260.
} 
niska samoocena członków grupy, dylematy moralne i trudności w podjęciu decyzji ${ }^{8}$.

Międzykulturowe badania nad syndromem myślenia grupowego dowodzą, że występuje on we wszystkich kulturach, choć nie w takim nasileniu jak w Stanach Zjednoczonych Ameryki ${ }^{9}$. Trzeba jednak zaznaczyć, że koncepcja syndromu myślenia grupowego zbudowana przez Janisa opiera się na analizie konkretnych przypadków, które posłużyły do zbudowania tejże teorii. Weryfikacja sformułowanych hipotez nie jest jeszcze ukończona, a dane empiryczne nie zawsze w całej rozciagłości ją potwierdzają, istnieje jednak wystarczająco dużo przesłanek, żeby stwierdzić istnienie opisywanego syndromu ${ }^{10}$.

Współcześnie próbuje się poszukiwać jeszcze innych, niż wymienione wcześniej, przyczyn powstawania tego zjawiska ${ }^{11}$. Niektórzy badacze uważają, że myślenie grupowe jest przejawem zwykłego zjawiska polegającego na tym, że w grupie przyjmuje się błędne procesy podejmowania decyzji, ponieważ jej członkowie silnie identyfikują się z grupa, która albo nie posiada żadnych procedur mających na celu skuteczne podejmowanie decyzji, albo obowiązują w niej normy zachęcające do myślenia grupowego ${ }^{12}$. Według takiej argumentacji, gdy tylko członkowie grupy poczują silną przynależność do niej, wówczas syndrom myślenia grupowego jest nieuniknionym produktem ubocznym ${ }^{13}$.

Warunki sprzyjające powstawaniu syndromu myślenia grupowego przystają do specyfiki grup kościelnych. Hermetyczność jest charakterystyczna dla większości grup doradczych w Kościele, a również wiele grup formacyjnych nie jest wolna od izolacjonizmu ${ }^{14}$. Poza tym $w$ kościelnych grupach doradczych $\mathrm{z}$ defini-

${ }^{8}$ Zob. Encyklopedia Blackwella. Psychologia spoleczna. Red. A. S. R. M a n ste a d, M. H e w stone [i in.]. Warszawa (J a c ek S a ntorski \& Co) brak roku polskiego wydania, s. 622.

${ }^{9}$ Por. C. K. O 1 s t e r, dz. cyt., s. 186.

${ }^{10}$ Por. B. W o j c i s z k e, dz. cyt., s. 403.

${ }^{11}$ Zob. M. A. H o g g: The social psychology og group cohesiveness: From attraction to social identity. London (Harvester Wheatsheaf) 1992; R.J. A 1 d a r: S.R. F u 11 e r: Beyond fiasco: A reappraisal of the groupthink phenomenonand a new model of group decisnion processes. „Psychological Bulletin”. R. 1993 nr 113 s. 533-552.

${ }^{12}$ Por. M. A. H o g g: The Social Psychology of Group Cohesivivness: From attraction to social identity. Hemel Hempstead (Harvester, Wheatsheaf) 1992 s. 135.

${ }^{13}$ Por. P. H a r t l e y: Komunikacja w grupie. Poznań (Zysk i S-ka) 2000 s. 170.

${ }^{14}$ Przykładem hermetycznej wspólnoty formacyjnej jest Droga Neokatechumenalna, która mimo teoretycznych założeń służby parafii, w pierwszym okresie formacyjnym, który praktycznie trwa wiele lat, niejako działa obok parafii terytorialnej. Posiada „własną” liturgię, spotyka się w salkach parafialnych i niechętnie przyjmuje nowych członków. Zresztą sugestie pastoralne papieża B e n e dykta X V I skierowane do Drogi w 2005 r. dotyczyły większego otwarcia na parafię i lokalne zwyczaje - zob. W. Śmigiel: Eklezjalność Drogi Neokatechumenalnej. „Roczniki Teologiczne". T. 54: 2007 z. 6 s. 365-377. 
cji występuje silny lider, który przy nieznajomości pewnych mechanizmów, może wywołać syndrom myślenia grupowego ${ }^{15}$.

Nie można też zapomnieć, że koncepcje eklezjologiczne dominujące w teologii do Soboru Watykańskiego II podkreślały hierarchiczność i piramidalną strukturę Kościoła, a walcząc z prądami liberalnymi coraz bardziej zamykały $\mathrm{i}$ izolowały środowiska kościelne. Dialog ze światem, jeśli był prowadzony, to z dużą rezerwą i ostrożnością. W praktyce prowadziło to do traktowania Kościoła jak „twierdzy”, którą trzeba bronić przed złymi prądami zewnętrznymi. Metodą działania była ucieczka od złych wpływów i wrogów Kościoła. Rodziło to atmosferę ciagłego poczucia zagrożenia. Taki sposób rozumienia Kościoła w eklezjologii został po Soborze Watykańskim II przezwyciężony, ale w świadomości wielu ludzi związanych z Kościołem nadal funkcjonuje.

Grupy kościelne, szczególnie doradcze, kiedy spotykają się z konkretnymi problemami, często mają poczucie zagrożenia, co skutkuje izolowaniem się od świata. Boją się o swoją przyszłość, obawiają się środowisk wrogich Kościołowi i nieprzychylnych mediów. Zaś z drugiej strony boją się ,narazić” hierarchii kościelnej propozycją zbyt śmiałych rozwiązań. Poza tym, jeśli mają one doradzać w trudnych sprawach, czują brzemię odpowiedzialności i w konsekwencji funkcjonują w dużym stresie. Wszystkie te czynniki niemalże modelowo przystają do warunków sprzyjających pojawieniu się syndromu myślenia grupowego.

\section{Symptomy i skutki myślenia grupowego}

W grupie, która uległa syndromowi myślenia grupowego, pojawia się złudzenie jednomyślności i odporności na ataki. Grupa ma poczucie nieomylności i siły, a także jest przekonana o swoich moralnych racjach („Bóg jest z nami”). W takich grupach występuje stereotypowe postrzeganie przeciwników, jako złych i nigdy nie mających racji. Poza tym syndrom myślenia grupowego wyzwala autocenzurę, czyli członkowie grupy dobrowolnie odrzucają poglądy sprzeczne z przekonaniem większości. Grupa bardzo spójna, w której pojawił się omawiany symptom, wywiera silny nacisk na dysydentów, którzy mają inne poglądy niż większość lub ich poglądy są w opozycji do poglądów przywódcy. Nacisk ma na celu zmuszenie dysydentów do zmiany stanowiska lub nawet wykluczenie z gru-

\footnotetext{
${ }^{15}$ Diecezjalne grupy doradcze mają służyć pomocą biskupowi diecezjalnemu w rozeznawaniu sytuacji duszpasterskiej i podejmowaniu decyzji. Biskupowi diecezjalnemu w powierzonej mu diecezji przysługuje wszelka władza zwyczajna, własna i bezpośrednia, jaka jest wymagana do spełniania jego urzędu (KPK kan. $381 \S 1$ ). Tak silna i scentralizowana władza, w niektórych przypadkach niezwykle skuteczna, naturalnie sprzyja pojawieniu się myślenia grupowego. Podobna sytuacja, choć w mniejszym zakresie dotyczy funkcjonowania rad parafialnych, którym przewodzi proboszcz parafii.
} 
py. W takich sytuacjach pojawią się też „strażnicy jednomyślności”, którzy chronią przywódcę przed odmiennymi poglądami. W praktyce, jeśli lider przedstawi jakąś propozycję, to „strażnicy” rozpoczynają batalię na rzecz poparcia jego tezy i zawsze bezkrytycznie przyznają mu rację. „Strażnicy” również odgrywają znaczącą rolę w eliminowaniu dysydentów - marginalizują lub ośmieszają ich propozycje $^{16}$.

Symptomy myślenia grupowego wywołują siedem przejawów wadliwej procedury podejmowania decyzji: ograniczona zostaje liczba dyskutowanych rozwiązań; początkowo proponowane propozycje nie podlegają ponownej weryfikacji; nie wraca się do rozwiązań odrzuconych w pierwszej fazie dyskusji; nie zasięga się opinii ekspertów, a docierające do grupy rady i sugestie są odbierane w sposób selektywny i tendencyjny; cele są ustalane w sposób niekompletny; reakcje i opinie ludzi spoza grupy nie są brane pod uwagę, co powoduje brak planów awaryjnych na wypadek niepowodzenia ${ }^{17}$.

Członkowie spójnej grupy są bezkrytyczni wobec siebie i swoich poglądów, a lekceważą te osoby, które się z nimi nie zgadzają. Dyrektywny styl przywództwa i coraz mniej logiczny sposób rozumowania prowadzą do odejścia $z$ grupy wszystkich, którzy nie myślą tak, jak większość. Taka grupa często tworzy normy, które są niezgodne z normami obowiązującymi w świecie zewnętrznym. Przez niektórych badaczy nazywane są one normami ucieczkowymi. Członkowie takiej grupy przyjmują postawę wyższość i obierają ludziom z zewnątrz prawo do zadawania pytań lub kwestionowania ich decyzji i zachowań. Często przywódca takiej grupy posiada duży autorytet, a jej członkowie starają się go zadowolić i zabiegają o jego przychylność. Ponieważ grupa jest zamknięta na głosy z zewnątrz, rodzi się w niej przekonanie, że wszyscy ludzie myślą tak samo. Nawet jeśli ktoś ma wątpliwości, to ich nie zgłasza, aby nie narazić się przywódcy i grupie $^{18}$.

Znając funkcjonowanie grup kościelnych nie sposób nie zauważyć, że są one szczególnie narażone na opisany sposób myślenia, a niektóre z nich już dawno mu uległy. W dużym uproszczeniu można przyjąć, że istnieją cztery grupy zagrożeń dla Kościoła ze strony zrzeszeń katolików świeckich. Pierwszym niebezpieczeństwem jest ekskluzywizm, drugim jest negacja instytucji i autorytetu, trzecim jest selektywizm wartości i norm, czwartym jest przesadny horyzontali$\mathrm{zm}^{19}$. Szczególnie ekskluzywizm prowadzi do pojawienia się syndromu myślenia

${ }^{16}$ Por. A r o n s o n, dz. cyt., s. 381.

${ }^{17}$ Zob. Encyklopedia Blackwella, dz. cyt., s. 622.

${ }^{18}$ Por. C. K. O y s t e r, dz. cyt., s. 186.

${ }^{19}$ Por. R. K a m iń s k i: Zrzeszenia religijne a parafia. W: $W$ prostocie prawdy, $w$ pokorze serca. Studia i materiat. T. B o r u t k a, A. B a c z y ń s k i, M. O st ro w s k i. Papieska Akademia Teologiczna w Krakowie. Wydział Teologiczny. Kraków 2008 s. 284-285. 
grupowego. Potrzeba bardzo roztropnego stylu przywództwa, aby taki stan rzeczy przełamać.

Skutkiem myślenia grupowego jest podejmowanie bardzo złych decyzji, które mogą być całkowicie nieracjonalne i dla grupy zgubne. Obserwując różne sytuacje w Kościele można stwierdzić, że wiele razy taki rodzaj myślenia doprowadził grupy formacyjne lub nawet zakony do poważnego kryzysy. W skrajnych przypadkach grupy zamieniały się w sektę. Przykładem może być zakon sióstr Betanek z Kazimierza Dolnego. Zaistniały tam wszelkie warunki wywołujące syndrom. Po pierwsze na czele klasztoru stała silna przełożona Jadwiga Ligocka, która przez współsiostry była uważana za charyzmatyczkę oraz rzekomo doznawała objawień prywatnych ${ }^{20}$. Zakon zupełnie zamknął się na świat zewnętrzny. Siostry żyły w poczuciu, że świat, do którego z czasem zaliczyły też Kościół, nie rozumie ich przesłania, a w konsekwencji jest nastawiony wrogo ${ }^{21}$. W działaniu sióstr pojawiło się szereg nieprawidłowości przeczących nauce i praktyce Kościoła katolickiego. Taka postawa doprowadziła do głębokiego kryzysu i w 2007 r. siostry zostały wydalone z zakonu i siłą zmuszone do opuszczenia budynku klasztoru. Te wydarzenia, przy dużym rozgłosie medialnym, uderzyły w autorytet zakonu i Kościoła, a także spowodowały poważne problemy prawne i psychologiczne wśród byłych sióstr Betanek. Przykład ten wskazuje wyraźnie, że w środowisku kościelnym myślenie grupowe może znaleźć podatny grunt, a w konsekwencji nie tylko utrudnia podejmowanie właściwych decyzji, ale nawet jest $\mathrm{w}$ stanie całkowicie „zaślepić” grupę.

Również wiele grup formacyjnych, wskutek pojawienia się syndromu myślenia grupowego, oderwało się od Kościoła lub podejmowało błędne decyzje. W 2008 r. poważne problemy zostały ujawnione w funkcjonowaniu, na terenie archidiecezji warszawskiej, Ruchu Rodzin Nazaretańskich (dalej RRN), skądinąd grupy o głębokiej duchowości i bardzo zasłużonej dla formacji chrześcijan. Abp Kazimierz Nycz powołał zewnętrzną komisję teologiczną, która wnikliwie przebadała materiały formacyjne oraz praktykę ruchu. Stwierdzono sporo nieprawidłowości, które swoje źródło miały w złej koncepcji przywództwa ruchu oraz w całkowitym podporządkowaniu członków dyscyplinie grupowej. RRN był też grupą bardzo hermetyczną i pojawiły się w nim typowe symptomy myślenia grupowego. RRN nie był w stanie samodzielnie przezwyciężyć nieprawidłowości, a nawet $\mathrm{w}$ wielu wymiarach nie dostrzegał swoich błędów. Po przestudiowaniu

\footnotetext{
${ }^{20}$ Prawdziwy charyzmat nigdy nie jest w stanie zanegować urzędu hierarchicznego, jak miało to miejsce w przypadku klasztoru w Kazimierzu Dolnym. Pojawiają się napięcia pomiędzy urzędem, a charyzmatem, ale są one twórcze, a nie destrukcyjne. Charyzmat i urząd są względem siebie komplementarne - zob. W. Ś mi g i e l: Relacja urzędu do charyzmatu $w$ teorii i praktyce pastoralnej. W: W prostocie prawdy, w pokorze serca, dz. cyt., s. 471-482.

${ }^{21}$ Por. M. S z e n t má r t o n i: Psychologia pastoralna. Kraków (Wydawnictwo WAM) 1995 s. $112-113$.
} 
wyników prac komisji abp K. Nycz, metropolita warszawski, dokonał zmiany liderów, zarządził ponowne zdefiniowanie charyzmatu, celów i zasad RRN, a także zlecił zredagowanie nowych statutów ${ }^{22}$.

\section{Sposoby uniknięcia syndromu myślenia grupowego}

Wydaje się, że głównym czynnikiem minimalizującym szanse wystąpienia myślenia grupowego jest właściwy styl przewodzenia grupie. Zbyt dyrektywny przywódca, narzucający własny punkt widzenia i zniechęcający członków grupy do szczerych wypowiedzi, zdecydowanie blokuje podejmowanie przez grupę dobrych decyzji. Jednak trzeba pamiętać, że demokratyczny styl przywództwa wcale nie jest najskuteczniejszy w każdej sytuacji i nie broni przez niebezpieczeństwem myślenia grupowego. Zasadniczo styl przewodzenia jest uzależniony od sytuacji, dojrzałości i kompetencji grupy ${ }^{23}$.

W literaturze najczęściej podaje się, że dość prostym sposobem uniknięcia syndromu myślenia grupowego jest wypowiadanie swojego zdania przez lidera jako ostatniego $\mathrm{w}$ grupie, tym samym nie sugeruje on odpowiedzi. Mądry przywódca powinien zachęcać do prezentacji odmiennych poglądów i sam prowokować do przedstawiania różnych punktów myślenia ${ }^{24}$.

W przypadku kościelnych grup formacyjnych, w celu weryfikacji własnych poglądów warto, co jakiś czas, zapraszać niezależnego eksperta, który z zewnątrz będzie w stanie ocenić działanie grupy oraz wskazać na pewne słabości lub nawet nieprawidłowości. Takim ekspertem może być kapłan lub członek innej grupy formacyjnej, albo specjalista $\mathrm{z}$ dziedziny dynamiki grupowej. Wizyta kogoś z zewnątrz mogłaby być potraktowana jak swego rodzaju superwizja dla całej grupy. Wydaje się sensowne, że w ramach parafii w spotkaniach grup powinien czasem uczestniczyć proboszcz, który jest odpowiedzialny za całość duszpasterstwa parafialnego. Nie chodzi tutaj o uroczyste spotkania z okazji świąt, ale o normalne robocze funkcjonowanie grupy.

W niektórych grupach można powołać instytucję tzw. ,adwokata diabła”, który z definicji zajmowałby się poszukiwaniem słabych punktów w rozumowaniu grupy. W literaturze niektórzy znawcy zagadnienia zachęcają do tworzenia

${ }^{22}$ Zob. Kuria Metropolitalna Wars zaw ska: Komunikat dotyczący Ruchu Rodzin Nazaretańskich z 29 stycznia 2009 [http://www.archidiecezja.warszawa.pl/upload/binaries/ dokumenty/dekret rrn.pdf - 24.05.2009].

23 Por. R. B rown: Procesy grupowe. Dynamika wewnatrzgrupowa i międzygrupowa. Gdańsk (Gdańskie Wydawnictwo Psychologiczne) 2006 s. 196.

${ }^{24}$ Por. H. H a m e r: Psychologia spoteczna. Teoria i praktyka. Warszawa (Difin) 2005 s. 258. 
podgrup lub organizowania spotkań kolejnej szansy ${ }^{25}$. Jednak nie zawsze takie metody można zastosować, szczególnie w przypadku kościelnych grup doradczych, które są dość hermetyczne i posiadają swoiste procedury uniemożliwiające wprowadzanie zmian.

W przypadku formacyjnych grup kościelnych trzeba również pamiętać o kryteriach, które pomagają ocenić eklezjalność grup oraz chronią je przed dewiacjami, w tym także przed syndromem myślenia grupowego. Kryteria eklezjalności $^{26}$ zostały wyliczone w Adhortacji apostolskiej Christifideles laici (ChL 30) ${ }^{27}$. Kierując się wskazówkami zawartymi w nauczaniu kościelnym oraz wnikliwie śledząc praktykę Kościoła można stwierdzić, że najłatwiejszymi do zweryfikowania, a jednocześnie kluczowymi kryteriami są: stosunek grup do hierarchii kościelnej, ich nastawienie do innych grup oraz relacja do Eucharystii. W Polsce we wszystkich grupach, które przechodziły kryzysy lub nawet zamieniły się w sektę jedno lub więcej z tych kryteriów nie zostało zachowane. Przeciwstawienie charyzmatu urzędowi, niedocenianie Eucharystii lub niechęć do innych wspólnot religijnych jest wyraźnym znakiem, że dane zrzeszenie odchodzi od komunii z Kościołem. Komplementarność poszczególnych grup formacyjnych i ich otwarcie na parafię, to naturalne warunki, które minimalizują niebezpieczeństwo pojawienia się syndromu myślenia grupowego.

W ocenie działania kościelnych grup zawsze priorytet powinny mieć racje teologiczne i kryteria eklezjologiczne. Kościelna grupa, która jest otwarta i świadoma swoich zadań ewangelizacyjnych jest w naturalny sposób mniej podatna na myślenie grupowe. Świadomość poszczególnych grup, że są bardzo ważne i obdarzone charyzmatem, ale mogą działać tylko w komunii z Kościołem i dla dobra Kościoła, również hartuje je przed zagrożeniami. Jednak nigdy nie wolno lekceważyć zdobyczy innych nauk. Wiedza na temat sprzyjających warunków, symptomów, skutków i metod przeciwdziałania myśleniu grupowemu z pewnością jest przydatna liderom grup religijnych i przedstawicielom hierarchii kościelnej.

\footnotetext{
${ }^{25}$ Por. tamże.

${ }^{26}$ Eklezjalność to zbiór cech i właściwości, wyrażających istotę Kościoła.

${ }^{27}$ Zob. także - M. Ł a s z c z y k: Eklezjalność wspótczesnych stowarzyszeń katolików świeckich i ruchów religijnych $w$ Polsce. Lublin 1992 [mps - ArBKUL).
} 